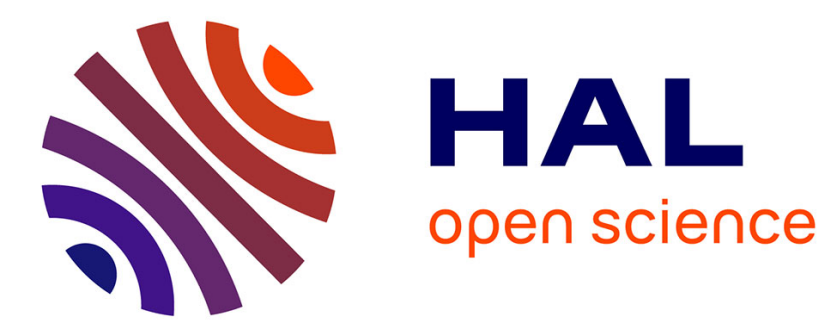

\title{
Foreign direct investment and bilateral investment treaties, an international political perspective
}

\author{
Rodolphe Desbordes, Vincent Vicard
}

\section{To cite this version:}

Rodolphe Desbordes, Vincent Vicard. Foreign direct investment and bilateral investment treaties, an international political perspective. 2007. halshs-00176051

\section{HAL Id: halshs-00176051 \\ https://shs.hal.science/halshs-00176051}

Submitted on 2 Oct 2007

HAL is a multi-disciplinary open access archive for the deposit and dissemination of scientific research documents, whether they are published or not. The documents may come from teaching and research institutions in France or abroad, or from public or private research centers.
L'archive ouverte pluridisciplinaire HAL, est destinée au dépôt et à la diffusion de documents scientifiques de niveau recherche, publiés ou non, émanant des établissements d'enseignement et de recherche français ou étrangers, des laboratoires publics ou privés. 


\section{Documents de Travail du Centre d'Economie de la Sorbonne}

.

.

.

W

0

1

K

1

n

g

P

a

$\mathrm{p}$

e

$r$

$\mathrm{S}$

Rodolphe DESBORDES, Vincent VICARD

2007.45 


\title{
Foreign Direct Investment and Bilateral Investment Treaties, an International Political Perspective*
}

\author{
Rodolphe Desbordes ${ }^{\dagger} \quad$ Vincent Vicard $^{\ddagger}$
}

July 2007

\begin{abstract}
Most of the literature dealing with the location of foreign direct investment (FDI) has ignored the fact that multinational enterprises (MNE) are not stateless and that their activities take place within an international political system: the return on their FDI can be greatly influenced by the quality of interstate political relations between their home and host countries. This paper investigates whether the quality of interstate political relations between countries influences the volume of bilateral FDI. Thanks to the construction of a new indicator of the quality of interstate political relations, it is found that better interstate political relations foster bilateral FDI, though the signature of a bilateral investment treaty (BIT) may dampen the impact of their fluctuations. In addition, the effect of a variation in the quality of domestic institutions increases with the entry into force of a BIT, suggesting that the latter signals the credibility of an institutional improvement. Overall, when both indirect effects are considered, the entry into force of a BIT increases bilateral FDI stocks by $16 \%$, on average, a lower impact than those found in previous studies. This effect nevertheless significantly differs according to the quality of both interstate political relations and domestic institutions.
\end{abstract}

Keywords: Foreign Direct Investment, Interstate Political Relations, Bilateral Investment Treaties, Institutions.

Résumé: La littérature sur la localisation des investissements directs à l'étranger (IDE) ignore, en grande partie, le fait que les entreprises multinationales ne sont pas apatrides et que leurs activités prennent place dans le système politique international. Leur retour sur investissement peut ainsi être grandement affecté par la qualité des relations politiques entre leur pays d'origine et le pays hôte de leurs investissements. Cet article étudie dans quelle mesure la qualité des relations politiques entre Etats influence le volume des IDE bilatéraux. En construisant un nouvel indicateur de la qualité des relations politiques internationales, nous montrons qu'entretenir de bonnes relations politiques favorise les IDE bilatéraux. La signature d'un traité bilatéral d'investissement (TBI) limite cependant la pertinence des relations politiques pour les décisions d'investissement. Par ailleurs, l'effet d'une amélioration des institutions domestiques augmente avec l'entrée en application d'un TBI, ce qui suggère que ces accords signalent la crédibilité des institutions domestiques. Dans l'ensemble, lorsque ces deux effets sont pris en compte, l'entrée en vigueur d'un TBI augmente les stocks bilatéraux d'IDE de 16\% en moyenne, un impact moins important que ceux trouvés dans les études précédentes. L'ampleur de cet effet varie cependant beaucoup selon la qualité des relations politiques entre Etats et des institutions domestiques.

Mots clés : Investissement direct à l'étranger, Relations politiques internationales, Traités bilatéraux d'investissement, Institutions.

JEL classification: F21, F53, F59

${ }^{*}$ We thank Keith Head, Thierry Mayer and Ian Wooton for their helpful comments. A previous version of the paper, entitled "Being nice makes you attractive: the FDI - international political relations nexus", circulated and was presented at the API conference in Beirut (2005), the AFSE congress in Paris (2006) and the RIEF conference in Roma (2007). We also thank Thierry Mayer and Farid Toubal for providing data.

${ }^{\dagger}$ IRES-UCL and University of Strathclyde. E-mail: desbordes@ires.ucl.ac.be.

${ }^{\ddagger}$ University of Paris I Panthéon-Sorbonne. E-mail: vincent.vicard@malix.univ-paris1.fr. 


\title{
1 Introduction
}

\author{
"Ulysses, too, saw the value of binding himself to the mast. Constraints on sovereignty \\ are, therefore, the aim of the exercise. In a world of international transactions and \\ multiple jurisdictions, constraints on sovereignty are also desirable. Otherwise, the \\ potential for conflict and unpredictability seems almost limitless" (Wolf, 2005, p.91)
}

The last century has demonstrated that international economic integration is not an automatic process. Trade barriers fell in the last century only because most countries mutually accepted to do so. Although today trade is regulated at the multilateral level, as attested by the growing importance of the World Trade Organization, international capital flows, especially foreign direct investment (FDI), do not benefit from global governance mechanisms which would enforce common rules across the globe. As suggested by Martin Wolf, in the absence of constraints on host country sovereignty, the activities of multinational enterprises (MNE) remain affected both by domestic governance and by the specific bilateral interstate relations between their home and host countries. Hence, in this paper we argue that previous literature has ignored an important determinant of FDI, by implicitly considering that FDI takes place within an international political vacuum, in which the policy choices of host countries are purely domestically driven. By apprehending the policy choices of host countries from an international perspective, this paper further contributes to the literature by providing the necessary framework to understand the effects of bilateral investment treaties (BITs).

Surveys, such as Transparency International (2002), clearly emphasise that, after corruption, diplomatic pressures are an important means for MNE to gain unfair business advantages. More crucially, foreign firms may suffer from the retaliatory consequences of deteriorating diplomatic relations between their home and host countries, through various devices of expropriation. Indeed Boehmer et al. (2001) show how valuable linkages, such as FDI, can be instrumentalised in interstate relations. It is therefore likely that foreign investors are very sensitive to the evolution of the quality of interstate political relations, since their deterioration could engender an increase in the risk of seizure of their return on investment in a given host country. On the other hand, an improvement in the quality of diplomatic relations should guarantee MNE a better protection of their property rights. The quality of interstate political relations should influence the volume of bilateral FDI, along with the quality of the domestic institutional framework. Hence, this paper contributes to existing literature by distinguishing two kinds of political risks: a systemic domestic risk, common to all investors, related to the quality of the domestic institutional framework, and an idiosyncratic risk specific to each pair of home and host countries, related to interstate political relations. Besides, positioning FDI theory into the broader context of interstate political relations 
provides a framework in which the effect of interstate agreements aiming at regulating investment flows, such as bilateral investment treaties, can be better understood. BITs act as an incomplete mechanism guaranteeing property rights at the supranational level. As such, they should reduce the diplomatic and domestic risks faced by MNE and, by extension, foster FDI.

The link between FDI and interstate political relations has been hardly investigated, due to the lack of information allowing the evaluation of the quality of the latter over the last decades. ${ }^{1}$ This obstacle is overcome in this paper thanks to the use of a new database which compiles a high number of recent interstate political interactions. The creation of an indicator of the quality of interstate political relations allows us to estimate their impact on bilateral FDI flows between 30 OECD countries and 62 OECD and non-OECD countries over the 1991-2000 period. It is found that the quality of diplomatic relations exerts a significant economic impact on bilateral FDI flows. However, its impact can be mitigated through the signature of a bilateral investment treaty. In addition, we find that the entry into force of a BIT increases bilateral FDI stocks by $16 \%$, on average, after taking into account its indirect effects. This total impact nevertheless varies significantly according to the quality of both interstate political relations and domestic institutions. Our results are based on a proper specification of the gravity equation, founded on its most recent econometric developments, and are robust to numerous robustness checks.

This paper proceeds as follows. Section 2 reviews the different arguments which may explain a causality link between interstate political relations, bilateral investment treaties and FDI. Section 3 describes the indicators used to evaluate the quality of interstate political relations and explains the specification and data used for the empirical estimation. The impact of interstate political relations and BITs on bilateral FDI stocks is then exposed in section 4. Section 5 concludes.

\section{Related literature}

\subsection{Foreign direct investment and interstate political relations}

Among the factors which influence the decision of a MNE to invest in a foreign country, the security of its property rights is particularly valued, because it guarantees the MNE that it will earn its full return on investment (Li and Resnick, 2003). Property rights must not only be protected against the actions of private agents (individuals or enterprises) but also against the State since it can abuse its "monopoly of legitimate violence" to expropriate investors in order to improve the welfare of its rulers. The concept of expropriation must be understood in a large

\footnotetext{
${ }^{1}$ Nigh (1985) is one of the few papers in the international business literature to have investigated this subject. He finds that conflictual and cooperative diplomatic relationships exert respectively a positive and negative impact on US manufacturing FDI in developing countries. His study is however specific to the diplomatic relationships of the United States, does not account for other FDI determinants, and only covers the particular period of the Cold War (1948-1978).
} 
sense: it corresponds to "[..] actions that state rulers take to improve their welfare by reducing the return on corporate investments" (Stulz, 2005, p.1597). North and Weingast (1989) show how the Stuarts, rulers of the United Kingdom in the XVII ${ }^{t h}$ century, expropriated the private sector thanks to the use of a variety of instruments: new taxes, forced loans rarely repaid, creation of monopoly grants, sale of peerages, purchase of goods below market price, threat of enforcement of forgotten regulations and, ultimately, seizure of private property. These instruments are still of use nowadays among public officials remains of actuality: Green (2005) reports that when the rulers of Beijing city decided to get involved in the production of vehicles, they issued a regulation stating that only the vehicles produced by the municipality-owned company could use three of the main thoroughfares leading to the city, hindering in this way private (foreign) producers.

It is likely that the degree of expropriation to which investors are confronted depends on their importance, in the eyes of state rulers, and on their specificities. One of the main criteria discriminating investors is their nationality. A government facing a reelection may gain from harming foreign investors if that allows to seduce a greater number of voters. Foreign investors, as informal representatives of their country, may also suffer from the degradation of the diplomatic relations between their home and host countries, since their expropriation can be used as a retaliatory instrument in an interstate conflict. Indeed, Boehmer et al. (2001) show how valuable interstate linkages, such as FDI, can serve as a costly signaling mechanism. These authors assume a rationalist explanation of war, i.e. that war is the consequence of the inability of two states to reach a negotiated arrangement, due to a lack of information on the preferences of the other. From this perspective, the ex-ante destruction of mutually valuable interstate economic linkages can be seen as a mean of communication through which disagreeing parties signal their resolve by sending a credible (and costly) signal. By reducing the uncertainty about the preferences of at least one actor, this signal favors the emergence of a peaceful negotiated settlement, without any military fight. International security concerns can thus lead a country to expropriate foreign investors. $^{2}$ Hence, MNE should invest less in countries where they are likely to suffer from interstate conflicts, since the risk of expropriation increases. A contrario, a rise in the quality of diplomatic relations between two countries should foster bilateral FDI, by guaranteeing MNE of both countries a better protection of their property rights.

\subsection{Foreign direct investment and bilateral investment treaties}

The expropriation risk sustained by MNE in the midst of interstate relations is related to the very structure of the international system, in which there is no supranational mechanism guaranteeing

\footnotetext{
${ }^{2}$ It is worth noting that in this case, the actions of expropriation undertaken by state rulers do not find their roots in the improvement of their own welfare but in the desire to avoid the recourse to the use of violence, which is inferior, in a Pareto sense, to a negotiated agreement which does not involve the loss of human lives and physical destruction.
} 
the protection of property rights and the enforcement of contracts. Countries may favor the partial implementation of such mechanism through the signatures of bilateral investment treaties (BITs), which strengthen the protection of foreign investors against the host country's actions of expropriation. In the broad perspective of the international political system, BITs can thus be understood as a mean to reduce the uncertainty related to bilateral interstate political relations.

BITs are signed between two countries in order to reciprocally encourage, promote and protect foreign investment in either country (UNCTAD, 2000). The nineties have experienced a surge in the number of BITs signed; BITs numbered 2495 in 2005, of which 1891 had entered into force, suggesting that more and more countries see them as a way to increase and protect their FDI outflows (figure $1^{3}$ ). The absence of discriminatory treatment against foreign investors, the prohibition of investment performance requirements or the possibility to repatriate profits without delays are provisions regularly included in BITs (UNCTAD, 2000). More remarkably, many BITs grant foreign investors the right to sue the host government through international arbitration, if actions undertaken by the host government are deemed to be tantamount to expropriation, i.e. a nationalisation or even a regulatory change (Hallward-Driemeier, 2003). This possibility of resorting to a supranational authority whose decisions are binding on governments is an example highlighting how BITs accord foreign investors a greater protection of their property rights than the one they would enjoy if they could only challenge governmental actions before national courts, which are not always very quick and fair. By giving up the use of retaliatory measures against MNE in a diplomatic conflict and accepting some limitation on their sovereignty, signatory governments state their credibility as third-party which secures property rights. ${ }^{4}$

With respect to domestic institutions, the desire of a country to "trade its sovereignty for credibility" (Elkins et al., 2004) can be interpreted in two different ways. In a first case, it can be considered that by signing a BIT, a country indicates that it is determined to offer foreign investors an institutional framework which better secures property rights than the current domestic institutional framework. From this perspective, a BIT acts as a substitute to domestic institutions which are little trusted by foreign investors. In a second case, the signature of a BIT signals foreign investors that a country will not damage the protection of property rights already granted by domestic institutions in order to achieve its national objectives and security choices: BITs and quality of domestic institutions would then be complementary.

Whatever the true nature of BITs, as substitutes or complements to high-quality domestic institutions, a positive impact of a BIT on the volume of FDI received by a host country from its

\footnotetext{
${ }^{3}$ See http://globstat.unctad.org/html/index.html

${ }^{4}$ Elkins et al. (2004) report that the governments of the Czech Republic, Liban and Ecuador had to pay 250, 266 et 70 US\$ millions respectively to foreign firms for having expropriated them.
} 


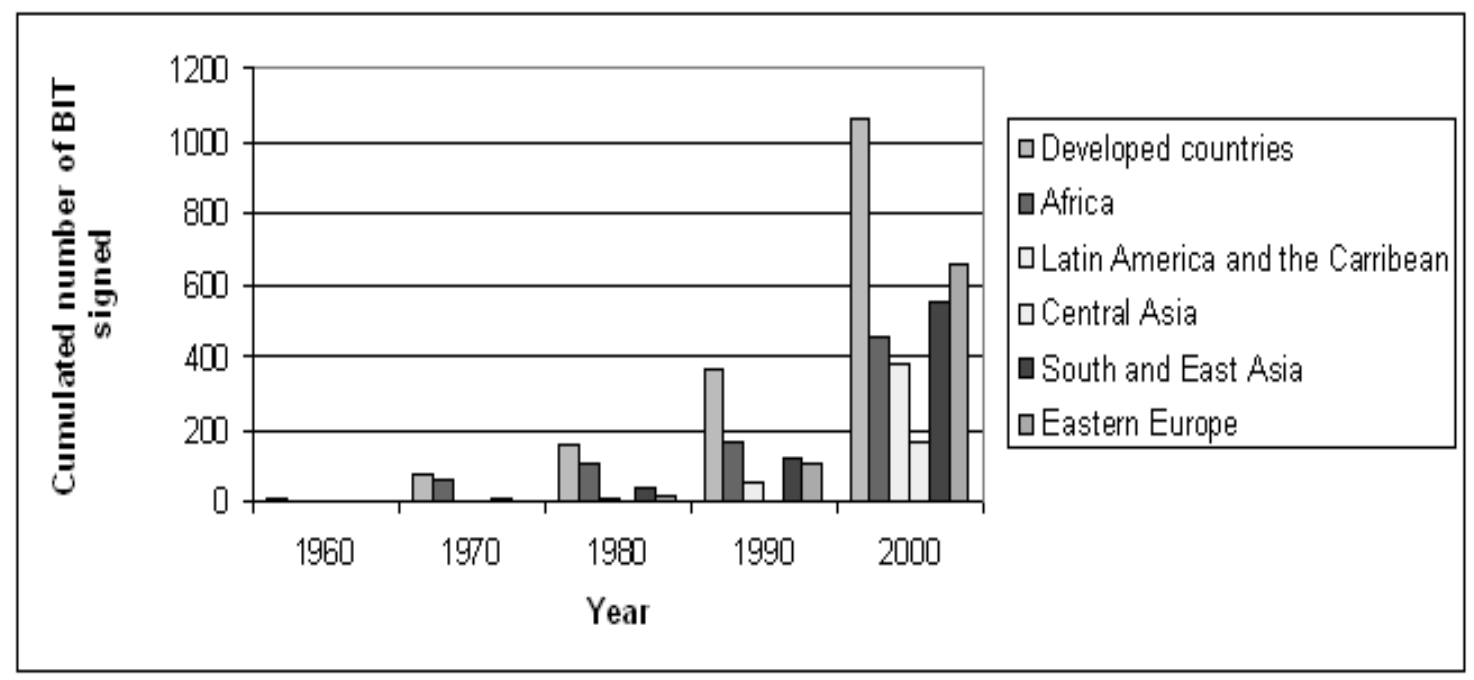

Source: UNCTAD FDI/TNC database

Figure 1: The growing participation of countries in bilateral investment treaties

signatory partner should be observed, since the entry into force of a BIT offers further guarantees to MNE about the security of their property rights and particularly on the absence of seizure of their return on investment by state rulers. Even in the absence of a BIT, MNE may be sensitive to the cumulative number of BITs already signed by the host country with other partners as the latter may be interpreted as the extent to which the international community acknowledges the host country's credibility. However, previous studies have found an ambiguous impact of BITs on FDI, ranging from positive (Egger and Pfaffermayr, 2004; Neumayer and Spess, 2005; Salacuse and Sullivan, 2005) to insignificant (Hallward-Driemeier, 2003; Rose-Ackerman and Tobin, 2005). This mixed impact of BITs on FDI may have two reasons. First, by relying in most cases on aggregate FDI data, previous studies have obscured the specific impact of a BIT on FDI between two partners. Second, these papers focus on the direct effect of BITs on FDI, omitting the different channels through which a BIT may influence the host country business environment. Hallward-Driemeier (2003) and Neumayer and Spess (2005) are two exceptions, and they reach opposite conclusions. Hallward-Driemeier (2003) finds evidence that BITs are complementary to good domestic institutions whereas Neumayer and Spess (2005) suggest that BITs function as substitutes for good domestic institutional quality. Hence, the existence of this indirect channel of influence of BITs on FDI remains highly controversial. In addition, the capacity of BITs to dampen the impact on FDI of variations in interstate political relations has been globally ignored. This is not surprising since diplomatic relations remain a "missing" determinant in the FDI literature. Overall, the total effects of BITs on FDI are unknown and studies finding a positive and significant impact, such as the $30 \%$ effect estimated by Egger and Pfaffermayr (2004), do not give much guidance on the channels through which a BIT increases bilateral FDI. 


\section{Empirical model and data}

It is expected that the quality of interstate political relations exerts an impact on the volume of bilateral FDI, as it influences the security of property rights enjoyed by foreign investors. However, in the presence of a BIT, their fluctuations may matter less since the host country agrees to grant foreign investors a stronger protection of their property rights by abiding to international rules. In addition, BITs may act as substitutes or complements to high-quality domestic institutions. Finally, maintaining good interstate political relations or signing a BIT with a given partner may exert an externality on FDI originating from other countries. Empirical testing of these four hypotheses will be achieved through the construction of an indicator of the quality of interstate political relations and the use of interaction terms within a gravity model of bilateral FDI.

\subsection{The quality of interstate political relations}

When working on interstate interactions, two types of data are available: qualitative data on armed conflicts and quantitative data on daily events. In the first case, actors, duration, geographical location and intensity of each conflict have been defined by researchers. Such efforts can only be undertaken for infrequent interstate interactions of a high intensity like armed conflicts. In the second case, daily events are automatically extracted by computers from wired reports or newspapers and are coded automatically by actors and type of observed actions. In comparison to armed conflicts datasets, it is quasi impossible to know whether these data globally pertain to the same united historical case. However data on daily events possess the great advantage of providing information about both conflictual and cooperative relations between states, whatever the intensity of the underlying event.

The evaluation of the quality of diplomatic relations between countries is based on a new event dataset, developed by the Kansas Events Data System (KEDS) and made available by Gary King on his website. ${ }^{5}$ Computers have been programmed to read the first sentence of news reports from wire services and to code each event according to the actor, the target, the type of event and the date. King and Lowe (2002) describe in detail this process and provide evidence that computer coding is equivalent to human coding in the short run and more efficient in the long run. The typology of events comes from Integrated Data for Events Analysis (IDEA, see Bond et al. (2003) for a complete description of the coding scheme).

In order to aggregate the daily events compiled in this data set, the level of conflict or cooperation embodied in each case needs to be taken into account. The Goldstein (1992) scale allows the transformation of daily interactions into two distinct annual flows of cooperative

\footnotetext{
${ }^{5}$ http: //gking. harvard.edu
} 
and conflictual interstate political relations. ${ }^{6}$ The values attributed to each category of event, reported in King and Lowe (2002), are indicated in appendix A. This scale gives a score between 0 and +10 (respectively 0 and -10 ) to each category of event according to the amount of cooperation (conflict) embodied in each event case. Both flows of cooperation and conflict are then combined into a single net indicator of the quality of interstate political relations (QIR) following the transformation proposed by Pollins $(1989):^{7}$

$$
Q I R_{i j t}=\operatorname{Coop}_{i j t} \times \frac{\operatorname{Coop}_{i j t}}{\operatorname{Coop}_{i j t}+\left|\operatorname{Conf}_{i j t}\right|}
$$

where Coop ijt $_{\text {and }}$ Conf $f_{i j t}$ stand for the flows of cooperative and conflictual interstate political relations between countries $i$ and $j$ in year $t$. This formula defines a single non-negative net indicator which allows the evaluation of the quality of interstate political relations between two countries. The higher the value, the higher the degree of cooperation between two states. A value of zero means that only conflictual or neutral events have occurred. Data is available over the 1991-2000 period for most dyadic interstate political relations.

\subsection{Model}

The workhorse econometric model for bilateral trade flows, i.e. the gravity model, is now increasingly used when investigating determinants of FDI flows. ${ }^{8}$ Head and Ries (2007) provide theoretical micro-foundations for a gravity model of FDI and motivate its use for modeling bilateral FDI as well as trade flows. Hence, our basic specification is the following:

$$
\begin{aligned}
\ln \left(F D I_{i j t}\right)= & \beta_{0}+\beta_{1} \ln \left(G D P_{i t}\right)+\beta_{2} \ln \left(G D P_{j t}\right)+\beta_{3} \ln \left(G D P P C_{i t}\right)+\beta_{4} \ln \left(G D P P C_{j t}\right) \\
& +\beta_{5} \ln \left(d_{i j}\right)+\beta_{6} C_{i j t}+\beta_{7} \ln \left(I C R G_{j t}\right)+\beta_{8} \ln \left(Q I R_{i j t}\right)+\beta_{9} B I T_{i j t}+\epsilon_{i j t}
\end{aligned}
$$

where $F D I_{i j t}$ stands for the bilateral stock of FDI in country $j$ originating from country $i$ in year $t, C_{i j t}$ is a vector of gravity-specific variables (distance, contiguity, common language), $I C R G_{j t}$ is a measure of the quality of domestic institutions, $Q I R_{i j t}$ is our proxy for the quality of interstate political relations, $B I T_{i j t}$ is a dummy variable for bilateral investment treaty between country $i$ and $j$, and $\epsilon_{i j t}$ corresponds to the sum of four terms: a home country time-invariant fixed effect, a host country time-invariant fixed effect, a country-invariant time effect and the error term. It is expected that bilateral FDI flows will be positively influenced by market sizes, contiguity, common language, quality of domestic institutions, quality of interstate political relations and

\footnotetext{
${ }^{6}$ The mapping of IDEA categories onto Goldstein scale, first developed for the World Event/Interaction Survey (WEIS), is available from IDEA's website (http://vranet.com/idea).

${ }^{7}$ Such transformation takes into account the interdependence between the level of cooperation and the level of conflict.

${ }^{8}$ See for instance Wei (2000) or Benassy-Quere et al. (2007).
} 
the entry into force of a BIT. Distance, as a proxy for transaction costs, should exert a negative impact. Finally, the sign of host country wealth is ambiguous since a high GDP per capita is simultaneously correlated with high purchasing power and high nominal wages, each exerting an opposite effect on FDI, positive and negative respectively (Globerman and Shapiro, 2002, 2003). Time-invariant omitted determinants are captured by both home and host countries fixed effects and time dummies control for the effect of worldwide factors which influence simultaneously all bilateral FDI stocks.

\subsection{Data and methodology}

Our dependent variable is bilateral FDI stocks [FDI]. It originates from the OECD International Direct Investment statistics database, which reports data for bilateral stocks among 30 OECD countries and between OECD countries and 32 non-OECD emerging countries, over the period 1991-2000. FDI stocks are preferred to FDI flows as the former are less volatile, which is particularly important when working with yearly data. All FDI stocks are converted into millions of current US dollars.

Out of 8001 observations, about $8 \%$ equal zero. A well-known problem of the log specification of the gravity model is the difficulty of accounting for zeros in the dependent variable, because dropping them could create a selection bias. Two strategies are implemented to deal with this problem. First, instead of using $\ln \left(F D I_{i j t}\right)$, we work with $\ln \left(F D I_{i j t}+1\right)$, which allows to avoid dropping the zero values. ${ }^{9}$ Our second, and preferred, strategy is to implement a Poisson quasi maximum likelihood estimator (QMLE). This strategy has been suggested by Santos Silva and Tenreyro (2006) concerning gravity models of trade flows (see Head and Ries (2007) for an application to FDI). They point out that standard log-linear models as well as Tobit models implemented to account for selection bias yield inconsistent estimates in the presence of heteroscedasticity. Their proposed estimation procedure, Poisson QMLE, is not only consistent in the presence of heteroscedasticity, but it also allows to incorporate zero values of the dependent variable in our regressions.

Data on GDP [GDP] and GDP per capita [GDPPC] are taken from the World Bank World Development Indicators database. GDP is in current US dollars and GDP per capita is in current PPP US dollars. Time-invariant bilateral characteristics (distance [d], contiguity and common language [C]) come from the CEPII. ${ }^{10}$ In addition, an important determinant of FDI flows is the quality of domestic institutions [ICRG] (Wei, 2000; Globerman and Shapiro, 2002; Benassy-Quere et al., 2007). Our proxy is the composite risk index originating from the International Country

\footnotetext{
${ }^{9}$ Results remain qualitatively similar when values different from 1 are added.

${ }^{10}$ www.cepii.fr
} 
Risk Guide, which aggregates into a single indicator evaluations of the political, economic and financial risks of a given country. ${ }^{11}$ The higher the composite index, ranging between 0 and 100 , the lower the risk perceived. The indicator of the quality of interstate political relations [QIR] has been introduced in section 3.1. Finally, the BIT dummy [BIT] takes the value one starting from the year when a BIT between two countries enters into force. ${ }^{12}$ Data on BITs come from the UNCTAD Investment Treaty Database. ${ }^{13}$

Summary statistics are given in table 1.

Table 1: Descriptive statistics

\begin{tabular}{l|ccccc}
\hline \hline & & & & & \\
Variable & Obs & Mean & Std. Dev. & Min & Max \\
\hline & & & & & \\
FDI & 8001 & 3025.28 & 12410.2 & 0 & 303591.7 \\
$\ln ($ FDI) & 7374 & 5.39 & 2.75 & -4.25 & 12.62 \\
$\ln$ (FDI+1) & 8001 & 5.04 & 2.88 & 0 & 12.62 \\
ln GDP origin & 8001 & 12.83 & 1.50 & 8.67 & 16.10 \\
ln GDP host & 8001 & 12.67 & 1.51 & 8.67 & 16.10 \\
ln Distance & 8001 & 8.24 & 1.10 & 4.09 & 9.88 \\
Contiguity & 8001 & 0.07 & 0.26 & 0 & 1 \\
Common language & 8001 & 0.08 & 0.27 & 0 & 1 \\
ln GDP per capita origin & 8001 & 9.68 & 0.61 & 7.26 & 10.44 \\
ln GDP per capita host & 8001 & 9.53 & 0.68 & 7.26 & 10.44 \\
ln ICRG host & 8001 & 4.35 & 0.12 & 3.77 & 4.52 \\
Quality of Interstate Relations & 8001 & 37.19 & 99.97 & 0 & 1778.64 \\
ln Quality of Interstate Relations (QIR) & 8001 & 2.37 & 1.59 & 0 & 7.48 \\
BIT & 8001 & 0.28 & 0.45 & 0 & 1 \\
\hline \hline
\end{tabular}

\section{Results}

\subsection{Quality of interstate political relations}

Results are given in table 2. In terms of control variables, from a host country perspective, a large market, good public governance, shared language and contiguity tend to exert a positive impact on bilateral investment, whereas the opposite is true for bilateral distance and GDP per capita. The sign of the latter can be interpreted as reflecting the impact of high labour costs. These results are in line with previous works using the same specification, such as Benassy-Quere et al. (2007) or Head and Ries (2007). Although the signs and significance of our control variables

\footnotetext{
${ }^{11}$ See www.icrgonline.com/page.aspx?page=icrgmethods for details on the 22 components of the ICRG composite index.

${ }^{12}$ Egger and Pfaffermayr (2004) show that a BIT increases significantly bilateral FDI only if it is actually implemented, underlining that the international commitment of the host country must appear to be credible to foreign investors. Hence, we use the date of entry into force of a BIT rather than its date of signature.

${ }^{13}$ http: //www . unctadxi .org/templates/Startpage_-_-_718.aspx
} 
are sensitive to the specification used, ${ }^{14}$ it is reassuring to note that the coefficient of our proxy for the quality of interstate political relations (QIR) is always positive and significant, indicating that countries entertaining good diplomatic relations invest more in each other. The economic effect is substantial since according to column (6) of table 2, a one standard deviation increase from the mean of the quality of interstate political relations increases the bilateral FDI stock by about $80 \%$.

Table 2: The impact of interstate political relations on FDI

\begin{tabular}{|c|c|c|c|c|c|c|}
\hline \multirow{3}{*}{$\begin{array}{l}\text { Model } \\
\text { Estimator: } \\
\text { Dependent variable }\end{array}$} & (1) & $(2)$ & (3) & $(4)$ & \multirow{2}{*}{\multicolumn{2}{|c|}{$\begin{array}{c}(5) \\
\text { Poisson QMLE }\end{array}$}} \\
\hline & \multicolumn{2}{|c|}{ OLS } & \multicolumn{2}{|c|}{ OLS } & & \\
\hline & $\ln (\mathrm{FDI})$ & $\ln (\mathrm{FDI})$ & $\ln (\mathrm{FDI}+1)$ & $\ln (\mathrm{FDI}+1)$ & FDI & FDI \\
\hline \multirow[t]{2}{*}{$\ln$ GDP origin } & $-0.33^{b}$ & $-0.32^{c}$ & -0.25 & -0.26 & 0.12 & 0.26 \\
\hline & $(0.18)$ & $(0.18)$ & $(0.16)$ & $(0.16)$ & $(0.22)$ & $(0.20)$ \\
\hline \multirow{2}{*}{ ln GDP host } & $0.98^{a}$ & $1.00^{a}$ & $0.85^{a}$ & $0.88^{a}$ & 0.23 & 0.40 \\
\hline & $(0.17)$ & $(0.18)$ & $(0.16)$ & $(0.16)$ & $(0.28)$ & $(0.25)$ \\
\hline \multirow[t]{2}{*}{ ln Distance } & $-0.96^{a}$ & $-0.86^{a}$ & $-0.99^{a}$ & $-0.89^{a}$ & $-0.46^{a}$ & $-0.37^{a}$ \\
\hline & $(0.06)$ & $(0.06)$ & $(0.06)$ & $(0.06)$ & $(0.05)$ & $(0.05)$ \\
\hline \multirow[t]{2}{*}{ Contiguity } & $0.64^{a}$ & $0.57^{a}$ & $0.55^{a}$ & $0.49^{a}$ & -0.12 & -0.18 \\
\hline & $(0.18)$ & $(0.17)$ & $(0.18)$ & $(0.17)$ & $(0.14)$ & $(0.13)$ \\
\hline \multirow[t]{2}{*}{ Common language } & $0.74^{a}$ & $0.64^{a}$ & $0.84^{a}$ & $0.73^{a}$ & $0.59^{a}$ & $0.52^{a}$ \\
\hline & $(0.19)$ & $(0.18)$ & $(0.19)$ & $(0.19)$ & $(0.10)$ & $(0.08)$ \\
\hline \multirow[t]{2}{*}{ ln GDP per capita origin } & $1.94^{a}$ & $1.82^{a}$ & $0.71^{c}$ & 0.58 & $3.14^{a}$ & $2.72^{a}$ \\
\hline & $(0.43)$ & $(0.45)$ & $(0.39)$ & $(0.33)$ & $(0.84)$ & $(0.79)$ \\
\hline \multirow[t]{2}{*}{ ln GDP per capita host } & -0.58 & $-0.77^{c}$ & -0.66 & $-0.89^{b}$ & $0.74^{c}$ & 0.41 \\
\hline & $(0.45)$ & $(0.45)$ & $(0.42)$ & $(0.36)$ & $(0.44)$ & $(0.39)$ \\
\hline \multirow[t]{2}{*}{ ln ICRG host } & $1.40^{a}$ & $1.46^{a}$ & $1.55^{a}$ & $1.63^{a}$ & $1.22^{b}$ & $1.05^{b}$ \\
\hline & $(0.37)$ & $(0.37)$ & $(0.34)$ & $(0.34)$ & $(0.52)$ & $(0.49)$ \\
\hline \multirow[t]{2}{*}{ ln Quality of Inter. Relations (QIR) } & & $0.17^{a}$ & & $0.19^{a}$ & & $0.31^{a}$ \\
\hline & & $(0.02)$ & & $(0.02)$ & & $(0.03)$ \\
\hline \multirow[t]{2}{*}{ Constant } & $-17.35^{a}$ & -4.65 & $-5.72^{a}$ & -2.70 & $-43.17^{a}$ & $-38.69^{a}$ \\
\hline & $(5.45)$ & $(5.01)$ & $(4.27)$ & $(5.10)$ & $(9.62)$ & $(8.60)$ \\
\hline Year fixed effects & Yes & Yes & Yes & Yes & Yes & Yes \\
\hline Country fixed effects & Yes & Yes & Yes & Yes & Yes & Yes \\
\hline Observations & 7374 & 7374 & 8001 & 8001 & 8001 & 8001 \\
\hline R-squared & 0.78 & 0.78 & 0.80 & 0.80 & 0.92 & 0.93 \\
\hline
\end{tabular}

Notes: a, b, c denotes respectively significance at the 1, 5 and $10 \%$ level. All variables are in logarithms. Heteroscedasticity- and autocorrelation-robust standard errors are in parentheses.

Our results may, however, suffer from endogeneity. The causality between FDI and interstate political relations may be bi-directional since according to the liberal peace paradigm, growing economic interdependence fosters better interstate political relations (Polachek, 1980; Oneal and Russett, 1997, 1999; Barbieri, 2002). In addition, omitted country-pair specific variables correlated with the quality of interstate political relations, may be the true factor driving the impact

\footnotetext{
${ }^{14}$ The lack of significance of GDP and GDP per capita may be explained by the inclusion of host and home country fixed effects and multicollinearity among these variables (because population varies slowly).
} 
of the quality of diplomatic relations on FDI. We deal with each problem consecutively, because no exogenous time-varying instrumental variable for the quality of interstate political relations is readily available and because the inclusion of country-pair fixed effects requires panel data.

The first source of endogeneity, simultaneity, can be accounted for by finding a suitable cross-sectional instrument. However, since even in cross-section we could not find good external instruments ${ }^{15}$, we resort to internal instruments, the lagged values of the quality of interstate political relations eight and nine years earlier. These lags have been chosen according to the first-stage $\mathrm{F}$ test statistic, the partial R-squared and the Hansen (1982) J tests of overidentifying restrictions. The first-stage $\mathrm{F}$ statistics and partial $\mathrm{R}^{2}$ indicate that these instruments can be regarded as "strong" since they respectively equal 47 - well above the Stock et al. (2002)'s rule of thumb of 10 -, and 0.23 , and the Sargan-Hansen test does not reject their exogeneity. Note that country-specific effects have been dropped in column (1) of table 3 and that the econometric methodology is two stage least squares.

To remedy to the second source of endogeneity, omitted variable, country-pair specific variables which could be correlated with the quality of interstate political relations are included in a first stage. In column (2), historical ties, i.e. the existence of a colonial relationship and the possibility that two countries used to belong to the same entity, e.g. Czech Republic and Slovakia, military conflict occurrence or signature of a regional trade agreement are accounted for. In a second stage, all time-invariant (unobservable) country-pair characteristics which may affect bilateral FDI, such as cultural proximity, are taken into account by the inclusion of country-pair specific fixed effects in column (3), in place of geographic and linguistic bilateral variables and country-specific effects. ${ }^{16}$ This is a particularly demanding specification since the impact of the quality of interstate political relations on FDI is only identified through the effect of its changes on FDI over time.

When endogeneity is controlled for, results provided in table 3 confirm our previous findings as the coefficient of the QIR variable always remains positive and significant. In the instrumental variable (IV) regression reported in column (1), the coefficient of the QIR variable remains significant and its magnitude is fairly close to what has been found previously. This is not surprising as a Durbin-Wu-Hausman test confirms the exogeneity of this variable. Results remain unchanged when controlling for additional determinants of bilateral FDI in column (2). It shows that historical ties influence bilateral FDI but do not drive the effect of the quality of diplomatic relations. However, in column (3), the coefficient of the latter decreases significantly as the inclusion of

\footnotetext{
${ }^{15}$ We tried to instrument the quality of interstate political relations with alliance similarity, UN vote correlation, religious similarity, or conflict history. However, the Sargan-Hansen test rejected in every case their exogeneity.

${ }^{16}$ We use the xtpqml Stata package developed by Tim Simcoe (http://www.rotman.utoronto.ca/timothy . simcoe/xtpqml.txt), which computes robust standard errors for fixed-effects Poisson models, as suggested by Wooldridge (1999).
} 
Table 3: The impact of interstate political relations: robustness checks

\begin{tabular}{|c|c|c|c|}
\hline $\begin{array}{l}\text { Model } \\
\text { Dependent variable } \\
\text { Estimator: }\end{array}$ & $\begin{array}{c}(1) \\
\ln (\mathrm{FDI}+1) \\
\text { IV }\end{array}$ & $\begin{array}{l}(2) \\
\text { FDI } \\
\text { Poisso }\end{array}$ & $\begin{array}{c}(3) \\
\text { FDI } \\
\text { QMLE }\end{array}$ \\
\hline $\ln$ GDP origin & $\begin{array}{l}0.73^{a} \\
(0.11)\end{array}$ & $\begin{array}{c}0.26 \\
(0.20)\end{array}$ & $\begin{array}{c}0.17 \\
(0.21)\end{array}$ \\
\hline ln GDP host & $\begin{array}{l}0.45^{a} \\
(0.11)\end{array}$ & $\begin{array}{c}0.39 \\
(0.25)\end{array}$ & $\begin{array}{c}0.29 \\
(0.26)\end{array}$ \\
\hline ln Distance & $\begin{array}{l}-0.49^{a} \\
(0.09)\end{array}$ & $\begin{array}{l}-0.37^{a} \\
(0.06)\end{array}$ & \\
\hline Contiguity & $\begin{array}{l}-0.24 \\
(0.24)\end{array}$ & $\begin{array}{l}-0.17 \\
(0.14)\end{array}$ & \\
\hline Common language & $\begin{array}{l}1.04^{a} \\
(0.22)\end{array}$ & $\begin{array}{c}0.37^{a} \\
0.09\end{array}$ & \\
\hline ln GDP per capita origin & $\begin{array}{l}1.87^{a} \\
(0.17)\end{array}$ & $\begin{array}{c}2.81^{a} \\
(0.80)\end{array}$ & $\begin{array}{l}3.22^{a} \\
(0.85)\end{array}$ \\
\hline ln GDP per capita host & $\begin{array}{l}-0.19 \\
(0.18)\end{array}$ & $\begin{array}{c}0.47 \\
(0.39)\end{array}$ & $\begin{array}{l}0.71^{c} \\
(0.40)\end{array}$ \\
\hline ln ICRG host & $\begin{array}{l}3.85^{a} \\
(1.12)\end{array}$ & $\begin{array}{l}1.06^{b} \\
(0.48)\end{array}$ & $\begin{array}{l}1.07^{b} \\
(0.49)\end{array}$ \\
\hline ln Quality of Inter. Relations (QIR) & $\begin{array}{l}0.23^{c} \\
(0.13)\end{array}$ & $\begin{array}{l}0.28^{a} \\
(0.03)\end{array}$ & $\begin{array}{l}0.09^{a} \\
(0.03)\end{array}$ \\
\hline Pair ever in a colonial relationship & & $\begin{array}{l}0.39^{a} \\
(0.10)\end{array}$ & $(0.02)$ \\
\hline Ever same country & & $\begin{array}{l}2.40^{a} \\
(0.35)\end{array}$ & \\
\hline Military Interstate Dispute & & $\begin{array}{c}0.01 \\
(0.10)\end{array}$ & \\
\hline Regional Trading Agreement & & $\begin{array}{c}0.16 \\
(0.12)\end{array}$ & \\
\hline Constant & $\begin{array}{l}3.47^{a} \\
(0.75) \\
\end{array}$ & $\begin{array}{c}-39.97^{a} \\
(8.87) \\
\end{array}$ & \\
\hline Year fixed effects & No & Yes & Yes \\
\hline Country fixed effects & No & Yes & No \\
\hline Country-pair fixed effects & No & No & Yes \\
\hline $\begin{array}{l}\text { Observations } \\
\text { Number of country pairs } \\
\text { Sargan-Hansen test }\end{array}$ & $\begin{array}{l}442 \\
0.72\end{array}$ & 7956 & $\begin{array}{l}7560 \\
1080\end{array}$ \\
\hline
\end{tabular}

\footnotetext{
Notes: a, b, c denotes respectively significance at the 1, 5 and $10 \%$ level.

All variables are in logarithms. Heteroscedasticity-robust standard errors are in parentheses. Autocorrelation-robust standard errors in column (1)-(2).
}

country-pair fixed effects implies that only the impact of differences in the quality of interstate political relations on bilateral FDI over time are investigated, leaving out the additional impact of inter-country differences in the quality level of interstate political relations. Nevertheless, in this demanding specification, the coefficient of the QIR variable remains significant at the $1 \%$ level, highlighting the importance of interstate political relations as a determinant of FDI. Together, these modifications of our initial specification demonstrate the robustness of the impact of the quality of interstate political relations on bilateral FDI. 


\subsection{Bilateral investment treaties}

To assess the total impact of BITs on FDI, their indirect effects on the host country business environment must be investigated. BITs may directly improve the business climate to which foreign investors are subject. Mostly, they may dampen or reduce the relevance in MNE location decisions of variations in both the quality of interstate political relations and the quality of domestic institutions. The last effect is, nevertheless, ambiguous as BITs may be substitute or complementary to a good public governance. In the latter case, the signature of a BIT can be seen as a costly signal sent by the host country to international investors about its resolution not to resort to retaliatory actions during a diplomatic crisis. In order to account for these indirect effects, interaction terms between the quality of interstate political relations and the existence of a BIT or the quality of domestic institutions are included in our basic specification. In table 4, we introduce consecutively our two interaction variables. The four first columns present results using country fixed effects, and the remaining four present results using country-pair fixed effects instead.

The coefficient and significance of the BIT variable depend on whether country-pair fixed effects are included (columns (1) and (5)). The fact that the coefficient is only significant in the specification including country-pair fixed effects suggests that countries "choose well" when signing a BIT, as suggested by Baier and Bergstrand (2007) concerning free trade agreements. For instance, when unobservable characteristics between two countries reduce their bilateral FDI flows, countries will be more likely to sign a BIT if the latter prevents these unobservable characteristics to deter bilateral FDI flows, i.e. if expected gains from signing a BIT are larger. As mentioned before, bilateral fixed effects control for the endogeneity bias related to omitted (unobservable) variables likely to affect both the level of bilateral FDI and the opportunity to enter a BIT. When such factors are taken into account, the effect of a BIT on bilateral FDI stock is positive and significant (column (5)).

Indirectly, BITs seem to mitigate the impact of the quality of interstate political relations on FDI, as the interaction term between both variables is always significant and negative across specifications (columns (2) and (6)). These findings imply that the signature of a BIT protects against the risk linked to interstate political relations. On the other hand, the interaction term between the BIT dummy and the quality of domestic institutions is not significant, whichever the specification used (column (3) and (7)). However, including the BIT dummy and the two interaction terms may be a misspecification if the effect of BIT on FDI is entirely dependent on the quality of both domestic institutions and interstate political relations. In other words, BITs may not have any direct effect and the coefficient of the BIT dummy in column (5) may only capture indirect effects, conditional on the values of the two institutional variables. The lack of 
Table 4: The impact of bilateral investment treaties on FDI

\begin{tabular}{|c|c|c|c|c|c|c|c|c|}
\hline $\begin{array}{l}\text { Model } \\
\text { Dependent variable } \\
\text { Estimator }\end{array}$ & $\begin{array}{l}(1) \\
\text { FDI }\end{array}$ & $\begin{array}{c}(2) \\
\text { FDI }\end{array}$ & $\begin{array}{c}(3) \\
\text { FDI }\end{array}$ & $\begin{array}{c}(4) \\
\text { FDI } \\
\text { Poisson } 6\end{array}$ & $\begin{array}{c}(5) \\
\text { FDI } \\
\text { MLE } \\
\end{array}$ & $\begin{array}{c}(6) \\
\text { FDI }\end{array}$ & $\begin{array}{c}(7) \\
\text { FDI }\end{array}$ & $\begin{array}{c}(8) \\
\text { FDI }\end{array}$ \\
\hline $\ln$ GDP origin & $\begin{array}{c}0.26 \\
(0.20)\end{array}$ & $\begin{array}{c}0.27 \\
(0.20)\end{array}$ & $\begin{array}{c}0.27 \\
(0.20)\end{array}$ & $\begin{array}{c}0.27 \\
(0.20)\end{array}$ & $\begin{array}{c}0.17 \\
(0.21)\end{array}$ & $\begin{array}{c}0.18 \\
(0.21)\end{array}$ & $\begin{array}{c}0.18 \\
(0.21)\end{array}$ & $\begin{array}{c}0.18 \\
(0.21)\end{array}$ \\
\hline ln GDP host & $\begin{array}{c}0.39 \\
(0.25)\end{array}$ & $\begin{array}{c}0.40 \\
(0.25)\end{array}$ & $\begin{array}{c}0.40 \\
(0.25)\end{array}$ & $\begin{array}{c}0.40 \\
(0.25)\end{array}$ & $\begin{array}{l}0.29^{a} \\
(0.26)\end{array}$ & $\begin{array}{c}0.29 \\
(0.26)\end{array}$ & $\begin{array}{c}0.29 \\
(0.26)\end{array}$ & $\begin{array}{c}0.29 \\
(0.26)\end{array}$ \\
\hline ln Distance & $\begin{array}{l}-0.37^{a} \\
(0.05)\end{array}$ & $\begin{array}{l}-0.37^{a} \\
(0.05)\end{array}$ & $\begin{array}{l}-0.37^{a} \\
(0.05)\end{array}$ & $\begin{array}{l}-0.37^{a} \\
(0.05)\end{array}$ & & & & \\
\hline Contiguity & $\begin{array}{l}-0.18 \\
(0.13)\end{array}$ & $\begin{array}{l}-0.19 \\
(0.13)\end{array}$ & $\begin{array}{l}-0.19 \\
(0.13)\end{array}$ & $\begin{array}{l}-0.19 \\
(0.13)\end{array}$ & & & & \\
\hline Common language & $\begin{array}{l}0.52^{a} \\
(0.08)\end{array}$ & $\begin{array}{l}0.51^{a} \\
(0.08)\end{array}$ & $\begin{array}{l}0.52^{a} \\
(0.08)\end{array}$ & $\begin{array}{l}0.51^{a} \\
(0.08)\end{array}$ & & & & \\
\hline ln GDP per capita origin & $\begin{array}{c}2.72^{a} \\
(0.79)\end{array}$ & $\begin{array}{l}2.72^{a} \\
(0.78)\end{array}$ & $\begin{array}{l}2.72^{a} \\
(0.79)\end{array}$ & $\begin{array}{l}2.72^{a} \\
(0.78)\end{array}$ & $\begin{array}{l}3.21^{a} \\
(0.85)\end{array}$ & $\begin{array}{l}3.20^{a} \\
(0.84)\end{array}$ & $\begin{array}{l}3.20^{a} \\
(0.84)\end{array}$ & $\begin{array}{l}3.20^{a} \\
(0.84)\end{array}$ \\
\hline ln GDP per capita host & $\begin{array}{c}0.42 \\
(0.39)\end{array}$ & $\begin{array}{c}0.42 \\
(0.39)\end{array}$ & $\begin{array}{c}0.42 \\
(0.39)\end{array}$ & $\begin{array}{c}0.42 \\
(0.39)\end{array}$ & $\begin{array}{c}0.72^{c} \\
(0.40)\end{array}$ & $\begin{array}{l}0.72^{c} \\
(0.40)\end{array}$ & $\begin{array}{l}0.72^{c} \\
(0.40)\end{array}$ & $\begin{array}{l}0.72^{c} \\
(0.40)\end{array}$ \\
\hline ln ICRG host & $\begin{array}{l}1.03^{b} \\
(0.49)\end{array}$ & $\begin{array}{l}1.04^{b} \\
(0.49)\end{array}$ & $\begin{array}{l}1.11^{b} \\
(0.49)\end{array}$ & $\begin{array}{l}1.02^{b} \\
(0.49)\end{array}$ & $\begin{array}{l}1.04^{a} \\
(0.49)\end{array}$ & $\begin{array}{l}1.05^{b} \\
(0.49)\end{array}$ & $\begin{array}{l}1.02^{a} \\
(0.53)\end{array}$ & $\begin{array}{l}1.03^{b} \\
(0.50)\end{array}$ \\
\hline ln Quality of Inter. Relations (QIR) & $\begin{array}{l}0.31^{a} \\
(0.03)\end{array}$ & $\begin{array}{l}0.32^{a} \\
(0.03)\end{array}$ & $\begin{array}{l}0.32^{a} \\
(0.03)\end{array}$ & $\begin{array}{l}0.32^{a} \\
(0.03)\end{array}$ & $\begin{array}{l}0.09^{a} \\
(0.02)\end{array}$ & $\begin{array}{l}0.10^{a} \\
(0.02)\end{array}$ & $\begin{array}{l}0.10^{a} \\
(0.02)\end{array}$ & $\begin{array}{l}0.10^{a} \\
(0.02)\end{array}$ \\
\hline BIT & $\begin{array}{c}0.09 \\
(0.11)\end{array}$ & $\begin{array}{l}0.41^{b} \\
(0.16)\end{array}$ & $\begin{array}{c}1.60 \\
(2.61)\end{array}$ & & $\begin{array}{l}0.24^{a} \\
(0.07)\end{array}$ & $\begin{array}{l}0.46^{a} \\
(0.12)\end{array}$ & $\begin{array}{l}-0.30 \\
(1.93)\end{array}$ & \\
\hline $\mathrm{BIT} * \mathrm{QIR}$ & & $\begin{array}{l}-0.11^{b} \\
(0.05)\end{array}$ & $\begin{array}{l}-0.11^{b} \\
(0.05)\end{array}$ & $\begin{array}{l}-0.11^{b} \\
(0.05)\end{array}$ & & $\begin{array}{l}-0.07^{b} \\
(0.03)\end{array}$ & $\begin{array}{l}-0.07^{b} \\
(0.03)\end{array}$ & $\begin{array}{l}-0.07^{b} \\
(0.03)\end{array}$ \\
\hline $\mathrm{BIT}^{*} \ln \mathrm{ICRG}$ host & & & $\begin{array}{l}-0.27 \\
(0.60)\end{array}$ & $\begin{array}{l}0.09^{b} \\
(0.04)\end{array}$ & & & $\begin{array}{c}0.18 \\
(0.45)\end{array}$ & $\begin{array}{l}0.11^{a} \\
(0.03)\end{array}$ \\
\hline Constant & $\begin{array}{c}-38.71^{a} \\
(8.60) \\
\end{array}$ & $\begin{array}{r}-38.77^{a} \\
(8.56) \\
\end{array}$ & $\begin{array}{r}-39.02^{a} \\
(8.60) \\
\end{array}$ & $\begin{array}{r}-39.70^{a} \\
(8.55) \\
\end{array}$ & & & & \\
\hline Year fixed effects & Yes & Yes & Yes & Yes & Yes & Yes & Yes & Yes \\
\hline Country fixed effects & Yes & Yes & Yes & Yes & No & No & No & No \\
\hline Country-pair fixed effects & No & No & No & No & Yes & Yes & Yes & Yes \\
\hline $\begin{array}{l}\text { Observations } \\
\text { Number of country pairs }\end{array}$ & 8001 & 8001 & 8001 & 8001 & $\begin{array}{l}7560 \\
1080\end{array}$ & $\begin{array}{l}7560 \\
1080\end{array}$ & $\begin{array}{l}7560 \\
1080\end{array}$ & $\begin{array}{l}7560 \\
1080\end{array}$ \\
\hline
\end{tabular}

Notes: a, b, c denotes respectively significance at the 1, 5 and 10\% level. All variables are in logarithms.

Heteroscedasticity-robust standard errors are in parentheses. Autocorrelation-robust standard errors in columns (1)-(4).

significance of the BIT dummy in column (3) and (7) provides support to this hypothesis. Once the BIT dummy is omitted in columns (4) and (8), both interaction terms become significant and it appears that the impact of a variation in the quality of domestic institutions increases with the signature of a BIT. It suggests that the latter signals the credibility of an institutional improvement, as the host country is less likely to damage the achieved quality of its domestic institutions for retaliation purposes. In appendix B, it is shown that results remain qualitatively unchanged when the ICRG composite risk indicator is replaced by a better proxy of property rights protection, the ICRG political risk indicator or when additional control variables are included (existence of a regional trading agreement, home and host country levels of democracy, 
membership to the GATT/WTO).

\subsection{Quantification of the BIT effect}

The quantification of the magnitude of the effect on bilateral FDI of the entry into force of a BIT between two countries is not straightforward because of the non-linear nature of our Poisson QMLE procedure and the interaction terms between a BIT and the quality of interstate relations and the quality of domestic institutions, respectively. Ai and Norton (2003) underline that the interaction effect is conditional on the independent variables. We decide therefore to assess the impact of BITs on FDI by simulating the effect of the entry into force of a BIT on the predicted bilateral FDI stocks from our Poisson QMLE model, holding everything else constant. By computing the predicted bilateral FDI stocks with and without a BIT, we are able to calculate the average effect of the entry into force of a BIT. For this, we use estimates of our preferred specification (column (8) of table 4). We also compute the average effect for different categories of country pairs, according to the institutional quality of the host country and the quality of bilateral interstate political relations.

When both indirect effects are considered, the entry into force of a BIT increases bilateral FDI stocks by $16 \%$ on average. This effect nevertheless significantly differs according to the values of the quality of both domestic institutions and interstate political relations (see figure 2). "Corner-effects" can be described. On the one hand, a BIT exerts little impact on FDI in a host country getting along well with its partner, whichever the quality of domestic institutions, since good diplomatic relations already guarantee foreign investors the protection of their property rights. Good domestic institutions nevertheless strengthen the credibility of the host country. On the other hand, a BIT exerts its strongest effects when foreign investors are confronted to recurrent diplomatic disputes as it assures foreign investors that they will not be the subject of retaliation through various devices of expropriation. The strongest impact of a BIT occurs when it clearly signals that the good domestic policies enjoyed by foreign investors are fully dissociated from the negative evolution of bilateral diplomatic relations. Overall, these results support our hypothesis that the purpose for a host country of signing a BIT is to send a costly signal stating its intertemporal credibility to foreign investors facing diplomatic risk.

\subsection{International externalities}

In this section, we investigate whether maintaining good interstate relations or signing a BIT with a given partner exerts any externality on FDI originating from other countries. First, a proxy for the quality of interstate political relations of a host country vis-a-vis all its partners is included. It is constructed as the average of bilateral interstate political relations weighted by the 


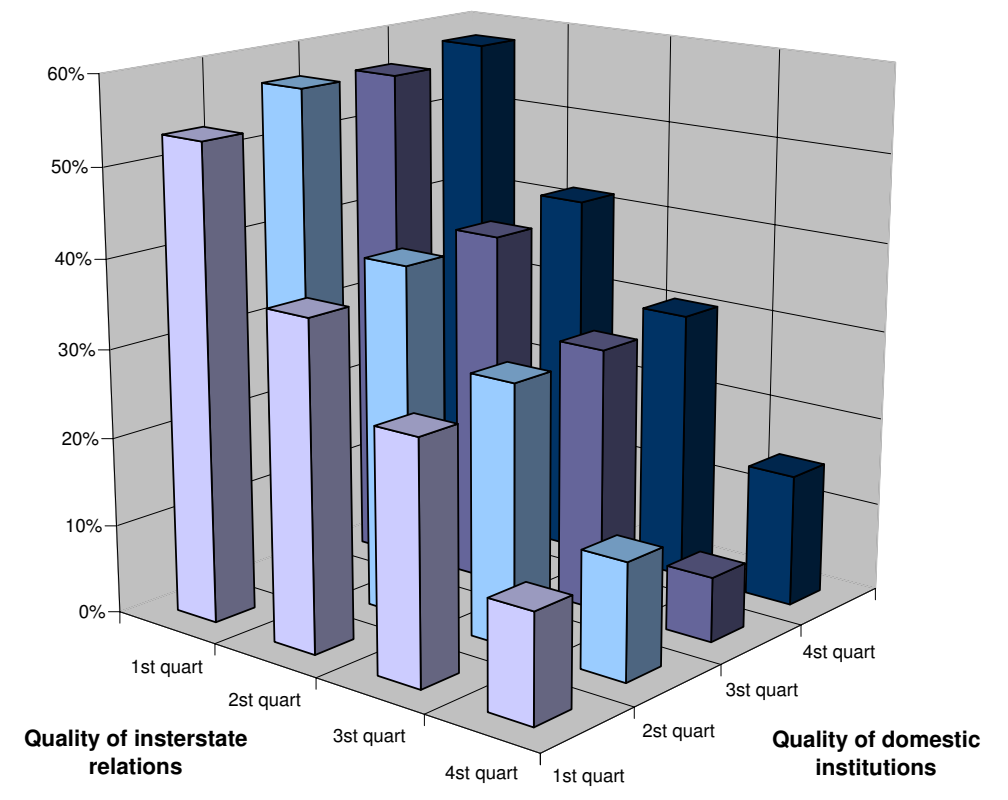

Figure 2: Total effect of the entry into force of a BIT by quality of domestic institutions and interstate political relations

market size of partner countries (GDP). Results are presented in columns (1) and (2) of table 5 . It appears that good interstate political relations with countries other than the partner country does not exert any positive impact on FDI. This suggests that the impact of interstate political relations on FDI are country-pair specific and that various foreign investors in the same host country will not experience the same protection of their property rights. In column (3), beyond the BIT dummy, the stock of BITs, i.e. the cumulative number of BITs that the host country has signed with all its partners, is included. ${ }^{17}$ Indeed, if BITs are complementary to good domestic institutions and act as a costly signal for their quality, BITs signed with other countries should also signal the good business climate in the host country to international investors even from non-signatory countries. In that case, it is found that FDI coming from a non-signatory country is positively influenced by the stock of BITs. This implies that a high number of BITs signals foreign investors that the host country has been judged credible, by the international community, in its determination to offer on a long term basis a business climate favorable to MNE. This last result confirms our previous findings.

\footnotetext{
${ }^{17}$ Data originate from the UNCTAD FDI database (http://stats.unctad.org/FDI/ReportFolders/ ReportFolders.aspx).
} 
Table 5: Bilateral FDI and multilateral externalities of bilateral relations

\begin{tabular}{|c|c|c|c|c|c|c|}
\hline $\begin{array}{l}\text { Model } \\
\text { Dependent variable } \\
\text { Estimator }\end{array}$ & $\begin{array}{c}(1) \\
\text { FDI }\end{array}$ & $\begin{array}{l}(2) \\
\text { FDI }\end{array}$ & $\begin{array}{c}(3) \\
\text { FDI } \\
\text { Poisson }\end{array}$ & $\begin{array}{c}(4) \\
\text { FDI } \\
\text { QMLE }\end{array}$ & $\begin{array}{c}(5) \\
\text { FDI }\end{array}$ & $\begin{array}{c}(6) \\
\text { FDI }\end{array}$ \\
\hline $\ln$ GDP origin & $\begin{array}{c}0.26 \\
(0.20)\end{array}$ & $\begin{array}{c}0.17 \\
(0.21)\end{array}$ & $\begin{array}{c}0.24 \\
(0.20)\end{array}$ & $\begin{array}{c}0.17 \\
(0.21)\end{array}$ & $\begin{array}{c}0.24 \\
(0.20)\end{array}$ & $\begin{array}{c}0.17 \\
(0.21)\end{array}$ \\
\hline ln GDP host & $\begin{array}{c}0.39 \\
(0.24)\end{array}$ & $\begin{array}{c}0.29 \\
(0.25)\end{array}$ & $\begin{array}{l}0.41^{c} \\
(0.25)\end{array}$ & $\begin{array}{c}0.30 \\
(0.26)\end{array}$ & $\begin{array}{l}0.41^{c} \\
(0.25)\end{array}$ & $\begin{array}{c}0.30 \\
(0.26)\end{array}$ \\
\hline ln Distance & $\begin{array}{l}-0.37^{a} \\
(0.05)\end{array}$ & & $\begin{array}{l}-0.37^{a} \\
(0.05)\end{array}$ & & $\begin{array}{l}-0.37^{a} \\
(0.05)\end{array}$ & \\
\hline Contiguity & $\begin{array}{l}-0.18 \\
(0.13)\end{array}$ & & $\begin{array}{l}-0.19 \\
(0.13)\end{array}$ & & $\begin{array}{l}-0.19 \\
(0.13)\end{array}$ & \\
\hline Common language & $\begin{array}{l}0.52^{a} \\
(0.08)\end{array}$ & & $\begin{array}{l}0.51^{a} \\
(0.08)\end{array}$ & & $\begin{array}{l}0.52^{a} \\
(0.08)\end{array}$ & \\
\hline ln GDP per capita origin & $\begin{array}{l}2.72^{a} \\
(0.78)\end{array}$ & $\begin{array}{l}3.22^{a} \\
(0.85)\end{array}$ & $\begin{array}{l}2.74^{a} \\
(0.76)\end{array}$ & $\begin{array}{l}3.18^{a} \\
(0.83)\end{array}$ & $\begin{array}{l}2.74^{a} \\
(0.76)\end{array}$ & $\begin{array}{l}3.18^{a} \\
(0.83)\end{array}$ \\
\hline ln GDP per capita host & $\begin{array}{c}0.42 \\
(0.39)\end{array}$ & $\begin{array}{l}0.71^{c} \\
(0.40)\end{array}$ & $\begin{array}{c}0.28 \\
(0.38)\end{array}$ & $\begin{array}{c}0.62 \\
(0.39)\end{array}$ & $\begin{array}{c}0.28 \\
(0.38)\end{array}$ & $\begin{array}{c}0.62 \\
(0.39)\end{array}$ \\
\hline ln ICRG host & $\begin{array}{l}1.07^{b} \\
(0.47)\end{array}$ & $\begin{array}{l}1.09^{b} \\
(0.47)\end{array}$ & $\begin{array}{l}0.97^{c} \\
(0.50)\end{array}$ & $\begin{array}{l}1.01^{b} \\
(0.49)\end{array}$ & $\begin{array}{l}0.95^{c} \\
(0.50)\end{array}$ & $\begin{array}{c}0.99^{b} \\
(0.50)\end{array}$ \\
\hline ln Quality of Inter. Relations (QIR) & $\begin{array}{l}0.31^{a} \\
(0.03)\end{array}$ & $\begin{array}{l}0.09^{a} \\
(0.02)\end{array}$ & $\begin{array}{l}0.32^{a} \\
(0.03)\end{array}$ & $\begin{array}{l}0.10^{a} \\
(0.02)\end{array}$ & $\begin{array}{l}0.32^{a} \\
(0.03)\end{array}$ & $\begin{array}{l}0.10^{a} \\
(0.00)\end{array}$ \\
\hline ln QIR multilateral host & $\begin{array}{c}0.02 \\
(0.05)\end{array}$ & $\begin{array}{c}0.01 \\
(0.05)\end{array}$ & & & & \\
\hline BIT & & & $\begin{array}{l}0.40^{a} \\
(0.16)\end{array}$ & $\begin{array}{l}0.40^{a} \\
(0.11)\end{array}$ & & \\
\hline BIT total host & & & $\begin{array}{l}0.45^{a} \\
(0.19)\end{array}$ & $\begin{array}{c}0.32^{b} \\
(0.17)\end{array}$ & $\begin{array}{l}0.44^{a} \\
(0.19)\end{array}$ & $\begin{array}{l}0.32^{c} \\
(0.17)\end{array}$ \\
\hline $\mathrm{BIT}^{*} \ln \mathrm{QIR}$ & & & $\begin{array}{l}-0.11^{b} \\
(0.05)\end{array}$ & $\begin{array}{r}-0.07^{a} \\
(0.03)\end{array}$ & $\begin{array}{l}-0.11^{b} \\
(0.05)\end{array}$ & $\begin{array}{l}-0.07^{b} \\
(0.03)\end{array}$ \\
\hline $\mathrm{BIT} * \ln$ ICRG host & & & & & $\begin{array}{c}0.09^{b} \\
(0.04)\end{array}$ & $\begin{array}{l}0.09^{a} \\
(0.03)\end{array}$ \\
\hline Constant & $\begin{array}{c}-38.80^{a} \\
(8.58) \\
\end{array}$ & & $\begin{array}{c}-38.06^{a} \\
(8.24) \\
\end{array}$ & & $\begin{array}{r}-37.98^{a} \\
(8.24) \\
\end{array}$ & \\
\hline Year fixed effects & Yes & Yes & Yes & Yes & Yes & Yes \\
\hline Country fixed effects & Yes & No & Yes & No & Yes & No \\
\hline Country-pair fixed effects & No & Yes & No & Yes & No & Yes \\
\hline $\begin{array}{l}\text { Observations } \\
\text { Number of country pairs }\end{array}$ & 8001 & $\begin{array}{l}7560 \\
1080\end{array}$ & 8001 & $\begin{array}{l}7560 \\
1080\end{array}$ & 8001 & $\begin{array}{l}7560 \\
1080\end{array}$ \\
\hline
\end{tabular}

Notes: $a, b, c$ denotes respectively significance at the 1, 5 and $10 \%$ level. All variables are in logarithms. Heteroscedasticity-robust standard errors are in parentheses.

Autocorrelation-robust standard errors in columns (1), (3) and (5).

\section{Conclusion}

Most of the literature dealing with the location of FDI has globally ignored that MNE are not stateless and that their activities take place within an international political system. When investing abroad, the business environment faced by MNE is not only shaped by the quality of domestic institutions: the return on their FDI can also be greatly influenced by the quality of interstate political relations between their home and host countries. This paper has tried to rem- 
edy to this omission of the literature by testing the impact of the quality of interstate political relations on bilateral FDI. Empirical results indicate that good interstate political relations positively influence FDI, although their effect can be mitigated by the effective existence of a BIT. Through the signature of a BIT, two partner countries reciprocally abandon the use of retaliatory actions against foreign firms and part of their sovereignty in order to credibly signal foreign investors their determination to offer a safe business climate on a long-term basis. In addition, the impact of a variation in the quality of domestic institutions increases with the signature of a BIT, suggesting that the latter signals the credibility of an institutional improvement. Overall, when both indirect effects are considered, the entry into force of a BIT increases bilateral FDI stocks by $16 \%$, on average, a lower impact than the one found in previous studies. The magnitude of this effect nevertheless significantly differs according to the quality of both host country domestic institutions and interstate political relations. 
Appendix A: Events and corresponding weights in Goldstein scale

\begin{tabular}{|c|c|c|c|}
\hline Definition & Goldstein & Definition & Goldstein \\
\hline Extend military aid & 8.3 & Comment & -0.1 \\
\hline Extend humanitarian aid & 7.6 & Decline comment & -0.1 \\
\hline Rally support & 7.6 & Pessimistic comment & -0.1 \\
\hline Extend economic aid & 7.4 & Ask for protection & -0.1 \\
\hline Improve relations & 5.4 & Deny & -1 \\
\hline Promise material support & 5.2 & Grant asylum & -1.1 \\
\hline Promise economic support & 5.2 & Criticize or blame & -2.2 \\
\hline Promise military support & 5.2 & Reduce routine activity & -2.2 \\
\hline Promise humanitarian support & 5.2 & Complain & -2.4 \\
\hline Agree & 4.8 & Informally complain & -2.4 \\
\hline Collaborate & 4.8 & Formally complain & -2.4 \\
\hline Promise & 4.7 & Accuse & -2.8 \\
\hline Promise policy support & 4.5 & Warn & -3 \\
\hline Endorse & 3.5 & Alerts & -3 \\
\hline Forgive & 3.5 & Denounce or denigrate & -3.4 \\
\hline Praise & 3.4 & Halt negotiations & -3.8 \\
\hline Empathize & 3.4 & Reject & -4 \\
\hline Solicit support & 3.4 & Reject proposal & -4 \\
\hline Ask for material aid & 3.4 & Refuse to allow & -4 \\
\hline Agree or accept & 3 & Defy norms & -4 \\
\hline Ease sanctions & 2.9 & Impose curfew & -4 \\
\hline Host a meeting & 2.8 & Censor media & -4 \\
\hline Assure & 2.8 & Veto & -4 \\
\hline Extend invitation & 2.5 & Political flight & -4 \\
\hline Grant & 2.2 & Disclose information & -4 \\
\hline Provide shelter & 2.2 & Break law & -4 \\
\hline Evacuate victims & 2.2 & Non-specific threats & -4.4 \\
\hline Observe truce & 2.2 & Arrest and detention & -4.4 \\
\hline Relax censorship & 2.2 & Political arrests and detention & -4.4 \\
\hline Relax administrative sanction & 2.2 & Criminal arrests and detention & -4.4 \\
\hline Demobilize armed forces & 2.2 & Administrative sanctions & -4.5 \\
\hline Relax curfew & 2.2 & Sanction & -4.5 \\
\hline Apologize & 2.2 & Strikes and boycotts & -4.5 \\
\hline Acknowledge responsibility & 2 & Demand & -4.9 \\
\hline Travel to meet & 1.9 & Expel & -5 \\
\hline Release or return & 1.9 & Protest demonstrations & -5.2 \\
\hline Request & 1.6 & Protest obstruction & -5.2 \\
\hline Ask for economic aid & 1.6 & Protest procession & -5.2 \\
\hline Ask for military aid & 1.6 & Protest defacement & -5.2 \\
\hline Ask for humanitarian aid & 1.6 & Reduce or stop aid & -5.6 \\
\hline Consult & 1.5 & Sanctions threat & -5.8 \\
\hline Offer peace proposal & 1.5 & Threaten & -6.4 \\
\hline Call for action & 1.2 & Non-military force threats & -6.4 \\
\hline Yield & 1.1 & Seize & -6.8 \\
\hline Discussions & 1 & Police seizure & -6.8 \\
\hline Propose & 0.8 & Other seizure & -6.8 \\
\hline Yield to order & 0.6 & Carjacking & -6.8 \\
\hline Yield position & 0.6 & Hostage taking and kidnapping & -6.8 \\
\hline Optimistic comment & 0.1 & Control crowds & -6.9 \\
\hline Ask for information & 0.1 & Demonstrate & -6.9 \\
\hline Animal incidents & 0 & Give ultimatum & -6.9 \\
\hline Economic activity & 0 & Protest altruism & -6.9 \\
\hline Other human action & 0 & Military force threats & -7 \\
\hline Human illness & 0 & Break relations & -7 \\
\hline Human death & 0 & Threaten military attack & -7 \\
\hline Economic status & 0 & Threaten military blockade & -7 \\
\hline Other human condition & 0 & Threaten military occupation & -7 \\
\hline Natural disaster & 0 & Threaten military war & -7 \\
\hline Accident & 0 & Military clash & -7 \\
\hline Other incident & 0 & Threaten nuclear attack & -7 \\
\hline Animal attack & 0 & Military alert & -7.6 \\
\hline Animal death & 0 & Military air display & -7.6 \\
\hline Animal illness & 0 & Military naval display & -7.6 \\
\hline
\end{tabular}




\begin{tabular}{llll} 
Definition & Goldstein & Definition & Goldstein \\
& & & \\
Other animal incident & 0 & Military troops display & -7.6 \\
Arts and entertainment performance & 0 & Military demonstration & -7.6 \\
Sports contest & 0 & Military mobilization & -7.6 \\
Transactions & 0 & Military border fortification & -7.6 \\
Government transactions & 0 & Riot or political turmoil & -8.3 \\
Private transactions & 0 & Bombings & -8.7 \\
Government default on payments & 0 & Seize possession & -9.2 \\
Default on payment & 0 & Abduction and hijacking & -9.2 \\
Elect representative & 0 & Military seizure & -9.2 \\
Administrative adjustment & 0 & Military occupation & -9.2 \\
Non-governmental adjustment & 0 & Military border violation & -9.2 \\
Judicial actions & 0 & Force & -9.6 \\
Infectious human illness & 0 & Physical assault & -9.6 \\
Non-infectious human illness & 0 & Beatings & -9.6 \\
Currency reserves & 0 & Shooting & -9.6 \\
Exchange rates & 0 & Bodily punishment & -9.6 \\
Equity prices & 0 & Sexual assault & -9.6 \\
Debt yields & 0 & Torture & -9.6 \\
Commodity prices & 0 & Assassination & -9.6 \\
Affective state & 0 & Military engagements & -10 \\
Beliefs and values & 0 & Military raid & -10 \\
Drought & 0 & Coups and mutinies & -10 \\
Earthquake & 0 & CBR weapons use & -10 \\
Flood & 0 & Grenade/RPG use & -10 \\
Hurricane & 0 & Suicide bombing & -10 \\
Tornado & 0 & Mine explosion & -10 \\
Volcano & 0 & Vehicle bombing & -10 \\
Tsunami & 0 & Chemical weapons use & -10 \\
Wildfire & 0 & & \\
Hazardous material spill & 0 & & \\
Private default on payments & 0 & & \\
Source: King and Lowe $(2002)$ & & & \\
\hline
\end{tabular}


Appendix B

Table 6: The impact of bilateral investment treaties on FDI: robustness analysis

\begin{tabular}{|c|c|c|}
\hline $\begin{array}{l}\text { Model } \\
\text { Dependent variable } \\
\text { Estimator }\end{array}$ & $\begin{array}{l}(1) \\
\text { FDI } \\
\end{array}$ & $\begin{array}{c}(2) \\
\text { FDI } \\
\text { QMLE }\end{array}$ \\
\hline ln GDP origin & $\begin{array}{c}0.20 \\
(0.21)\end{array}$ & $\begin{array}{c}0.21 \\
(0.21)\end{array}$ \\
\hline ln GDP host & $\begin{array}{c}0.31 \\
(0.23)\end{array}$ & $\begin{array}{c}0.31 \\
(0.26)\end{array}$ \\
\hline ln GDP per capita origin & $\begin{array}{l}3.21^{a} \\
(0.88)\end{array}$ & $\begin{array}{c}3.25^{a} \\
(0.86)\end{array}$ \\
\hline ln GDP per capita host & $\begin{array}{l}0.75^{c} \\
(0.41)\end{array}$ & $\begin{array}{c}0.73^{c} \\
(0.40)\end{array}$ \\
\hline ln ICRG host & & $\begin{array}{c}0.82^{c} \\
(0.47)\end{array}$ \\
\hline ln Quality of Inter. Relations (QIR) & $\begin{array}{c}0.10^{a} \\
(0.02)\end{array}$ & $\begin{array}{c}0.10^{a} \\
(0.02)\end{array}$ \\
\hline $\mathrm{BIT} * \mathrm{QIR}$ & $\begin{array}{c}-0.07^{b} \\
(0.03)\end{array}$ & $\begin{array}{c}-0.07^{b} \\
(0.03)\end{array}$ \\
\hline $\mathrm{BIT} * \ln \mathrm{ICRG}$ host & & $\begin{array}{c}0.11^{a} \\
(0.03)\end{array}$ \\
\hline ln ICRG pol. host & $\begin{array}{c}0.69^{b} \\
(0.33)\end{array}$ & \\
\hline BIT * ln ICRG pol. host & $\begin{array}{c}0.13^{a} \\
(0.03)\end{array}$ & \\
\hline Regional Trading Agreement & & $\begin{array}{c}0.21^{c} \\
(0.12)\end{array}$ \\
\hline Level of democracy (home country) & & $\begin{array}{c}0.26 \\
(0.36)\end{array}$ \\
\hline Level of democracy (host country) & & $\begin{array}{c}-0.52^{c} \\
(0.31)\end{array}$ \\
\hline GATT/WTO membership (host country) & & $\begin{array}{c}0.08 \\
(0.06)\end{array}$ \\
\hline Year fixed effects & Yes & Yes \\
\hline Country-pair fixed effects & Yes & Yes \\
\hline Observations & 7560 & 7452 \\
\hline Number of country pairs & 1080 & 1059 \\
\hline
\end{tabular}

Notes: a, b, c denotes respectively significance at the 1, 5 and $10 \%$ level. All variables are in logarithms. Heteroscedasticity-robust standard errors are in parentheses. 


\section{References}

Ai, C. and Norton, E. C. (2003), "Interaction terms in logit and probit models", Economics Letters, vol. $80 \mathrm{n}^{0}$ 1: pp. 123-129.

Baier, S. L. and Bergstrand, J. H. (2007), "Do Free Trade Agreements Actually Increase Members' International Trade?", Journal of International Economics, vol. $71 \mathrm{n}^{0}$ 1: pp. $72-95$.

BARBIERI, K. (2002), The liberal illusion: does trade promotes peace?, Ann Arbor: University of michigan Press.

Benassy-Quere, A., Coupet, M. and Mayer, T. (2007), "Institutional Determinants of Foreign Direct Investment", The World Economy, vol. 30 no 5: pp. 764-782.

Boenmer, C., A, G. E. and Li, Q. (2001), "Investing in the Peace: Economic Interdependence and International Conflict", International Organization, vol. $55 \mathrm{n}^{0}$ 2: pp. 391-438.

Bond, D., Bond, J., Oh, C., Jenkins, J. C. and Taylor, C. L. (2003), "Integrated Data for Events Analysis (IDEA): An Event Typology for Automated Events Data Development", Journal of Peace Research, vol. $40 \mathrm{n}^{0}$ 6: pp. 733-745.

Egger, P. and Pfaffermayr, M. (2004), "The impact of bilateral investment treaties on foreign direct investment", Journal of Comparative Economics, vol. $32 \mathrm{n}^{0}$ 4: pp. 788-804.

Elkins, Z., Guzman, A. T. and Simmons, B. (2004), "Competing for Capital: The Diffusion of Bilateral Investment Treaties, 1960-2000", UC Berkeley Public Law Research Paper, nº578961.

Globerman, S. and Shapiro, D. (2002), "Global Foreign Direct Investment Flows: The Role of Governance Infrastructure", World Development, vol. 30 nº 11: pp. 1899-1919.

Globerman, S. and Shapiro, D. (2003), "Governance Infrastructure and U.S. Foreign Direct Investment", Journal of International Business Studies, vol. $34 \mathrm{n}^{0}$ 1: pp. 19-39.

Goldstein, J. S. (1992), "A Conflict-Cooperation Scale for WEIS International Events Data", Journal of Conflict Resolution, vol. $36 \mathrm{n}^{\mathrm{0}}$ 2: pp. 369-385.

Green, P. L. (2005), "Giving Managers 'the creeps", Risk \& Insurance, vol. February.

Hallward-Driemeier, M. (2003), "Do Bilateral Investment Treaties Attract Foreign Direct Investment? Only a Bit ... and They Could Bite", World Bank Working Paper, nº 3121.

Hansen, L. (1982), "Large Sample Properties of Generalizes Method of Moments Estimators", Econometrica, vol. $50 \mathrm{n}^{0}$ 3: pp. 1029-1054.

HEAD, K. and RiES, J. (2007), "FDI as an outcome of the Market for Corporate Control: Theory and Evidence", Journal of International Economics, forthcoming.

King, G. and Lowe, W. (2002), "An Automated Information Extraction Tool for International Conflict Data with Performance as Good as Human Coders: A Rare Events Evaluation Design", International Organization, vol. 57 nº summer: pp. 617-642.

Li, Q. and Resnick, A. (2003), "Reversal of Fortunes: Democratic Institutions and Foreign Direct Investment Inflows to Developing Countries", International Organization, vol. $57 \mathrm{n}^{0} 5$ : pp. $175-211$.

Neumayer, E. and Spess, L. (2005), "Do Bilateral Investment Treaties Increase Foreign Direct Investment to Developing Countries?", World Economy, vol. 33 n 10: pp. 1567-1585. 
Nigh, D. (1985), "The Effect of Political Events on United States Direct Foreign Investment: A Pooled Time-Series Cross-Sectional Analysis", Journal of International Business Studies, vol. $16 \mathrm{n}^{0} 1$ : pp. 1-17.

North, D. C. and Weingast, B. R. (1989), "Constitutions and Commitment: The Evolution of Institutions Governing Public Choice in Seventeenth-Century England", The Journal of Economic History, vol. $49 \mathrm{n}^{0}$ 4: pp. 803-832.

Oneal, J. R. and Russett, B. M. (1997), "The classical liberals were rigth: democracy, interdependence and conflict, 1950-1985", International Studies Quarterly, vol. $41 \mathrm{n}^{0}$ 2: pp. $267-294$.

Oneal, J. R. and Russett, B. M. (1999), "Assessing the liberal peace with alternative specifications: trade still reduce conflicts", Journal of Peace Research, vol. 36 no 4: pp. 423-442.

PolacheK, S. W. (1980), "Conflict and trade", Journal of Conflict Resolution, vol. $24 \mathrm{n}^{0} 1$ : pp. 57-78.

Pollins, B. M. (1989), "Conflict, Cooperation and Commerce: the Effect of International Political Interactions on Bilateral Trade Flows", American Journal of Political Science, vol. 33 $\mathrm{n}^{0}$ 3: pp. $737-761$.

Rose-Ackerman, S. and Tobin, J. (2005), "Foreign Direct Investment and the Business Environment in Developing Countries: The Impact of Bilateral Investment Treaties", Yale Law \& Economics Research Paper, ${ }^{\circ} 293$.

Salacuse, J. W. and Sullivan, N. P. (2005), "An Evaluation of BITs \& Their Grand Bargain", Harvard International Law Journal, vol. $46 \mathrm{n}^{0} 1$.

Santos Silva, J. and Tenreyro, S. (2006), "The Log of Gravity", Review of Economics and Statistics, vol. 88 n $^{0}$ 4: pp. 641-658.

Stock, J. H., Wright, J. H. and Yogo, M. (2002), "A Survey of Weak Instruments and Weak Identification in Generalized Method of Moments", Journal of Business and Economic Statistics, vol. $20 \mathrm{n}^{0}$ 4: pp. 518-529.

Stulz, R. M. (2005), "The Limits of Financial Globalization", The Journal of Finance, vol. 9 $n^{0} 4$ : pp. $1595-1638$.

Transparency International (2002), "Bribe Payers Index 2002: explanatory notes and comparative tables", Http://www.transparency.org/.

UNCTAD (2000), Bilateral Investment Treaties 1959-1989, New-York: United Nations.

WeI, S.-J. (2000), "How Taxing is Corruption International Investors?", Review of Economics and Statistics, vol. $82 \mathrm{n}^{0}$ 1: pp. 1-11.

Wolf, M. (2005), Why globalization works, Yale University Press: New Haven and London.

Wooldridge, J. (1999), "Distribution-free estimation of some nonlinear panel data models", Journal of Econonmetrics, vol. $90 \mathrm{n}^{0}$ 1: pp. 77-97. 